\title{
5. MIDDLE MIOCENE TO UPPER QUATERNARY DIATOM BIOSTRATIGRAPHY OF THE IZU-BONIN/MARIANA REGION, EAST PACIFIC OCEAN ${ }^{1}$
}

\author{
Bjørg Stabell ${ }^{2}$
}

\begin{abstract}
Diatoms are present in lower middle Miocene through Holocene sediments recovered during Leg 125 in the Izu-Bonin region of the east Pacific Ocean, whereas diatoms are rare and without age-diagnostic species in the Mariana region. The diatom assemblage in the Izu-Bonin region is dominated by species characteristic of a low-latitude pelagic environment, but middle to high latitude species also were encountered. Age-diagnostic species occur sporadically and can be assigned only to several separated zones that range in age from middle Miocene to Holocene.
\end{abstract}

\section{INTRODUCTION}

During Leg 125, 15 holes were drilled at nine sites (Fig. 1) between the deep ocean trenches and island-arc volcanoes of the Mariana (Sites 778 through 781) and Izu-Bonin (Sites 782 through 786) regions south of Japan (Fryer, Pearce, Stokking, et al., 1990).

Diatom biostratigraphy of the Mariana region was investigated by DSDP scientists previously during Legs 59 and 60 and near the Izu-Bonin region by DSDP scientists during Leg 31 (Sites 296 through 298). Both investigations report only rare occurrences of diatoms, with the exception of mass occurrences of Ethmodiscus rex in the Mariana region.

The diatom zonation proposed by Barron (1985a, 1985b) for the equatorial Pacific was generally used during Leg 125 . In addition, the middle- to high-latitude zonations of Barron (1985b) and Akiba (1986) were consulted.

\section{METHODS}

Shipboard and subsequent shore-based sample preparation followed standard procedures. In a $250-\mathrm{mL}$ beaker, $10 \% \mathrm{HCl}$ was added to $1 \mathrm{~cm}^{3}$ of sediment until the carbonate reaction ceased, then it was heated in $10 \% \mathrm{H}_{2} \mathrm{O}_{2}$ and washed repeatedly in distilled water. Strewn slides of cleaned material were prepared using a Hyrax mounting medium, and the diatom valves were then identified at magnifications of $1000 x$

\section{RESULTS}

\section{Sites 778 through 781, Mariana Region}

In the Mariana region, upper Quaternary to upper Pliocene sediments were recovered. Diatoms, with the exception of Ethmodiscus rex fragments, are generally rare. No age-diagnostic species were observed. E. rex fragments were common in Cores 125-779A-1R and 125-779B-1R and abundant in Cores 125$781 \mathrm{~A}-1 \mathrm{R}$ and $-15 \mathrm{R}$.

\section{Site 782}

Site $782\left(30^{\circ} 51.60^{\prime} \mathrm{N}, 141^{\circ} 18.60^{\prime} \mathrm{E}\right.$; water depth, $\left.2958 \mathrm{~m}\right)$ is located on the eastern margin of the Izu-Bonin forearc basin, about

\footnotetext{
${ }^{1}$ Fryer, P., Pearce, J. A., Stokking, L. B., et al., 1992. Proc. ODP, Sci. Results, 125: College Station, TX (Ocean Drilling Program).

${ }^{2}$ Department of Geology, University of Oslo, P.O. Box 1047, Blindern, N-0316 Oslo
}

halfway between the active volcanic arc and the trench (Fig. 1). Hole $782 \mathrm{~A}$ penetrated to $476.8 \mathrm{mbsf}$.

The absence of age-diagnostic species in many samples resulted in large unzoned intervals. However, one may date the sedimentary interval in Hole 782A as ranging from the Quaternary to the middle Miocene.

Sample 125-782A-1H-CC was assigned to the Pseudoeunotia doliolus Zone (Fig. 2) by the presence of $P$. doliolus and absence of Nitzschia reinholdii. Sample 125-782A-2H-CC was placed in the $N$. reinholdii Zone by the co-occurrence of $N$. reinholdii and $P$. doliolus.

Samples $125-782 \mathrm{~A}-6 \mathrm{H}-\mathrm{CC}$ to $-8 \mathrm{H}-\mathrm{CC}$ were assigned to the late Pliocene Rhizosolenia praebergonii Zone, based on the occurrence of $R$. praebergonii. Samples 125-782A-9H-CC through 125-782A14X-CC contain Nitzschia jouseae and belong to the (lower $R$. praebergonii-) N. jouseae Zone. Rosiella tatsunokuchiensis without $N$. jouseae occur in Sample 125-782A-21X-CC, which was assigned to the Thalassiosira convexa Zone.

Nitzschia miocenica without $N$. reinholdii appears in Sample $125-782 \mathrm{~A}-22 \mathrm{X}-\mathrm{CC}$; this sample was placed in the late Miocene $N$. miocenica Zone. The occurrence of Actinocyclus moronensis, Crucidenticula punctata (Denticulopsis punctata f. hustedti), and Coscinodiscus plicatus without Hemidiscus cuneiformis in Sample 125-782A-27X-CC and the occurrence of Thalassiosira (Coscinodiscus) yabei, C. lewisianus, Craspedodiscus coscinodiscus, and Crucidenticula (Denticulopsis) nicobarica in Sample 125-782A$32 \mathrm{X}-\mathrm{CC}$, places this interval in the middle Miocene Coscinodiscus gigas var. diorama Zone.

\section{Site 783}

Site $783\left(30^{\circ} 57.86^{\prime} \mathrm{N}, 141^{\circ} 47.27 \mathrm{E}\right.$; water depth, $\left.4646.8 \mathrm{~m}\right)$ is located on the northern, mid-flank portion of a seamount that forms part of a ridge, more than $500 \mathrm{k}$ il long, that runs along the lowermost, inner wall of the Izu-Bonin Trench (Fig. 1). The seamount at this site has a thin sedimentary cover, perhaps in part because it lies at the distal end of a prominent submarine canyon system. Hole 783A reached a depth of 168.2 mbsf. Only three samples from the hole contained age-diagnostic species.

Sample 125-783A-1R-1, $1 \mathrm{~cm}$, contains Nitzschia reinholdii, and Sample 125-783A-1R-CC is characterized by Pseudoeunotia doliolus and $N$. reinholdii. The whole of this core was assigned to the N. reinholdii Zone (Fig. 2).

Sample 125-783A-5R-CC can be dated to the late Pliocene Rhizosolenia praebergonii Zone by the presence of $R$. praebergonii and the absence of $P$. doliolus. Nitzschia jouseae is present in Sample $125-783 \mathrm{~A}-10 \mathrm{R}-\mathrm{CC}$. This sample was assigned to the (lower $R$. praebergonii-) $N$. jouseae Zone. 

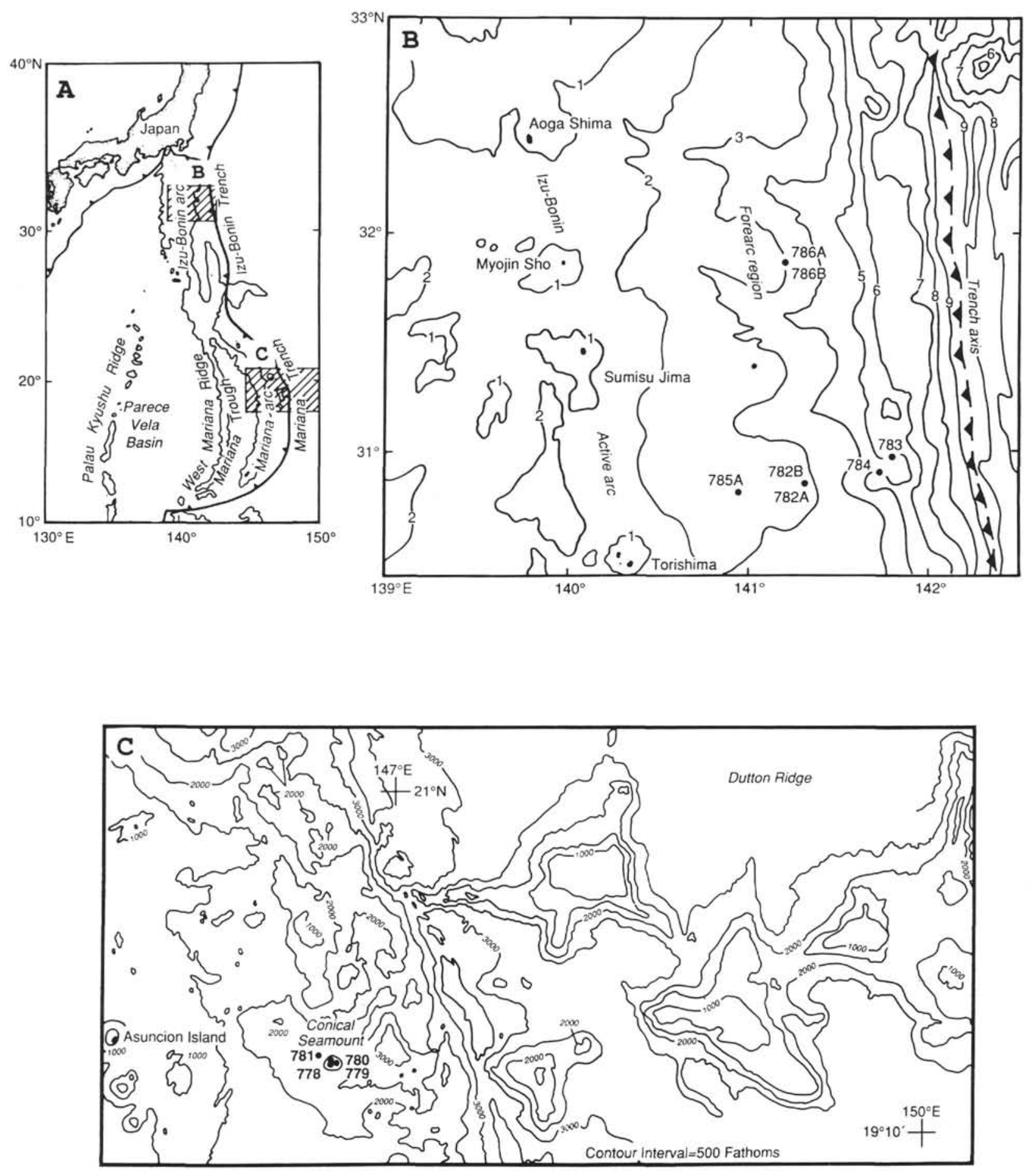

Figure 1. ODP Leg 125 sites investigated in the Izu-Bonin and Mariana area. A. Regional setting. B. Precise setting of drill sites (Sites 782 through 786) in the Izu-Bonin region. C. Precise setting of drill sites (Sites 778 through 781) in the Mariana region. 


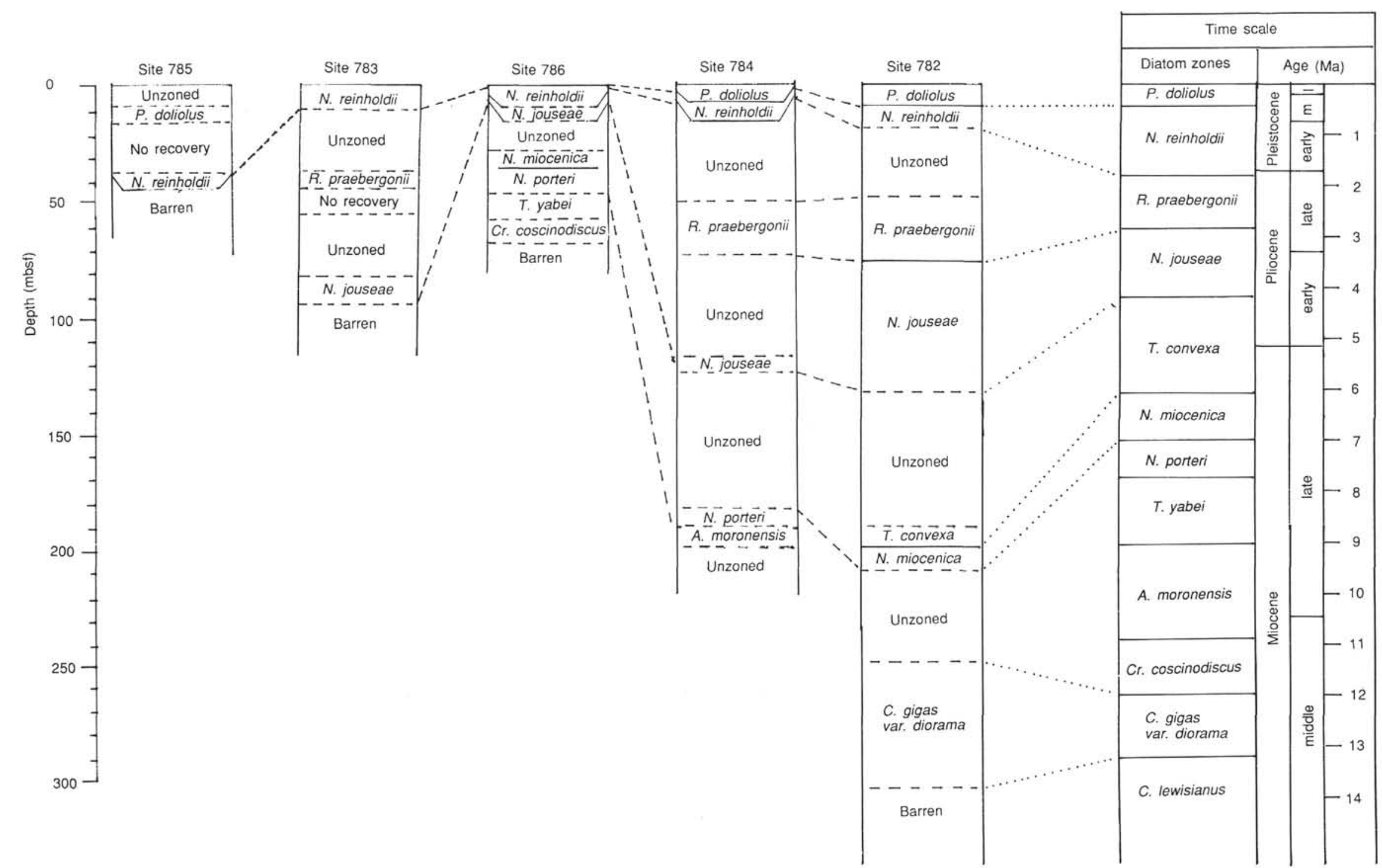




\section{Site 784}

Site $784\left(30^{\circ} 54.49^{\prime} \mathrm{N}, 141^{\circ} 44.27^{\prime} \mathrm{E}\right.$; water depth, $\left.4900.8 \mathrm{~m}\right)$ is located about $4 \mathrm{nmi}$ away from Site 783 on the lowermost, western flank of the same seamount, on the inner wall of the Izu-Bonin Trench (Fig. 1). Hole 784A penetrated to 425.3 mbsf. The scattered occurrence of age-diagnostic species left several intervals unzoned; as a whole the sedimentary interval ranges from late Pleistocene to earliest middle Miocene. The interval below Core 125-784A-31R-CC is devoid of diatoms.

Sample 125-784A-1R-1, 10-20 cm, was assigned to the Pseudoeunotia doliolus Zone by the occurrence of $P$. doliolus without Nitzschia reinholdii (Fig. 2). $N$. reinholdii, together with $P$. doliolus, was found in Sample 125-784A-1R-1, 81-82 cm, which places this sample in the $N$. reinholdii Zone.

Rhizosolenia praebergonii is present in Sample 125-784A-7R-1, 23-24 cm, and occurs together with Neodenticula koizumii (Denticula seminae and Nitzschiajouseae in Sample 125-784A-9R-3, 114-115 cm, so that this interval can be assigned to the late Pliocene $R$. praebergonii Zone. Neodenticula (Denticulopsis) kamtschatica, Nitzschia jouseae, and Rossiella tatsunokuchiensis are present in Sample 125-784A-14R-5, $43-44 \mathrm{~cm}$, and place this interval in the $N$. jouseae Zone.

Thalassiosira burckliana without Thalassiosira (Coscinodiscus) yabe $i$ is present from Sample 125-784A-21R-3, 39-40 cm, to -21R$\mathrm{CC}$, and thus, this interval was assigned to the late Miocene Nitzschia porteri zone. Denticulopsis hustedtii and Thalassiosira (Coscinodiscus) yabei, together with Hemidiscus cuneiformis, were recorded in Samples 125-784A-22R-6, 24-25 cm, to-22R-CC; these occurrences place this sample in the Actinocyclus moronensis Zone.

\section{Site 785}

Site $785\left(30^{\circ} 49.47^{\prime} \mathrm{N}, 140^{\circ} 55.17^{\prime} \mathrm{E}\right.$; water depth, $\left.2660.8 \mathrm{~m}\right)$ is located in the center of the Izu-Bonin forearc basin about $40 \mathrm{nmi}$ east-northeast of the active volcano, Torishima (Fig. 1). Hole 785A reached 104.7 mbsf.

Only two samples contained age-diagnostic species. Sample 125$785 \mathrm{~A}-2 \mathrm{H}-\mathrm{CC}$ was assigned to the Pseudoeunotia doliolus Zone (Fig. 2) because of the presence of $P$. doliolus and the absence of Nitzschia reinholdii. Both $P$. doliolus and $N$. reinholdii are present in Sample $125-785 \mathrm{~A}-5 \mathrm{X}-\mathrm{CC}$, so that this sample can be assigned to the $N$. reinholdii Zone.

\section{Site 786}

Site $786\left(31^{\circ} 52.48^{\prime} \mathrm{N}, 141^{\circ} 13.58^{\circ} \mathrm{E}\right.$; water depth, $\left.3058.1 \mathrm{~m}\right)$ is located in the center of the Izu-Bonin forearc basin about $120 \mathrm{nmi}$ east of the active volcano, Myuojin Sho (Fig. 1). Hole 786A penetrated to $166.5 \mathrm{mbsf}$.

The upper sample, $125-786 \mathrm{~A}-1 \mathrm{H}-1,0 \mathrm{~cm}$, was assigned to the Nitzschia reinholdii Zone (Fig. 2) by the occurrence of $N$. reinholdii, Pseudoeunotia doliolus, and Rhizosolenia praebergonii.

Nitzschia jouseae is present in Sample 125-786A-1H-CC, and this sample can be assigned to the late Pliocene (lower $R$. praebergonii-) N. jouseae Zone.
Nitzschia miocenica occurs in Sample 125-786A-4X-CC, which was assigned to the late Miocene $N$. miocenica Zone. $N$. porteri was found in Sample 125-786A-5H-CC; this sample has been tentatively placed in the $N$. porteri Zone. Thalassiosira (Coscinodiscus) yabei and Thalassiosira plicatus occur in Sample 125-786A-6H-CC, which was assigned tentatively to the $C$. yabei Zone. Sample 125-786A-7X$\mathrm{CC}$ contains Crucidenticula punctata (Denticulopsis punctata $\mathrm{f}$. hustedtii), allowing one to assign this sample to the earliest middle Miocene Craspedodiscus coscinodiscus Zone.

\section{CONCLUSIONS}

Sites 778 through 781 in the Mariana region are characterized by rare occurrences of diatoms, with the exception of common to abundant Ethmodiscus rex fragments. Age-diagnostic species were not observed.

In the Izu-Bonin region, diatoms occur from the earliest middle Miocene Coscinodiscus gigas var. diorama Zone to the present. The sporadic occurrence of age-diagnostic species, however, left several unzoned intervals. The three sites have a diatom biostratigraphy that extends to the Miocene (Sites 782, 784, and 786). When combined, all diatom zones in the earliest middle Miocene to Holocene interval are represented.

The occurrence of middle- to high-latitude species, such as Rosiella tatsunokuchiensis, Neodenticula kamtschatica, and N. koizumii, indicates a northern (colder) influence during the early Pliocene.

\section{ACKNOWLEDGMENTS}

This study was improved after careful review by Richard Batterbee and Patrick Coleman. I thank the Norwegian Research Council for Science and the Humanities (NAVF) and Nansenfondet for funding this work.

\section{REFERENCES}

Akiba, F., 1986. Middle Miocene to Quaternary diatom biostratigraphy in the Nankai Trough and Japan Trench, and modified lower Miocene through Quaternary diatom zones for middle to high latitudes of the North Pacific. In Kagami, H., Karig, D. E., Coulbourn, W. T., et. al., Init. Repts. DSDP, 87: Washington (U.S. Govt. Printing Office), 393-481.

Barron, J. A., 1985a. Late Eocene to Holocene diatom biostratigraphy of the equatorial Pacific Ocean, Deep Sea Drilling Project Leg 85. In Mayer, L., Theyer, F., et al., Init. Repts. DSDP, 85: Washington, (U.S. Govt. Printing Office), 413-456.

-, 1985b. Miocene to Holocene planktic diatoms. In Bolli, H. M., Saunders, J. B., and Perch-Nielsen, K. (Eds.), Plankton Stratigraphy: Cambridge (Cambridge Univ. Press), 763-810.

Fryer, P., Pearce, J. A., Stokking, L. B., et al., 1990. Proc. ODP, Init. Repts. 125: College Station, TX (Ocean Drilling Program).

Date of initial receipt: 3 October 1990

Date of acceptance: 6 May 1991

Ms 125B-144 